\title{
DEVELOPMENT AND VALIDATION OF TELMISARTAN IN TABLET DOSAGE FORM BY RP-HPLC ASSAY TECHNOLOGY
}

\author{
George Kumar Saha ${ }^{1}$, Beena Kumari ${ }^{2}$, Prabhat Kumar Upadhyay ${ }^{3}$, Manish \\ Kumar $^{1, \bowtie}$, Shailendra Bhatt ${ }^{1}$, Vipin Saini ${ }^{4}$, Neha Sharma ${ }^{4}$, Sonia Narwal ${ }^{5}$ \\ and Manisha Bhatia ${ }^{1}$ \\ ${ }^{1}$ M.M. College of Pharmacy, Maharishi Markandeshwar (Deemed to be University), \\ Mullana, Ambala, Haryana, India \\ ${ }^{2}$ Department of Pharmaceutical Sciences, Indira Gandhi University, \\ Meerpur, Rewari, Haryana, India \\ ${ }^{3}$ Institute of Pharmaceutical Research, GLA University, Mathura-281406, Uttar Pradesh, India \\ ${ }^{4} \mathrm{M}$ M University, Solan, H.P., India \\ ${ }^{5}$ Faculty of Pharmaceutical Sciences, PDM University, Bahadurgarh-124506, Haryana, India \\ ${ }^{\circledR}$ Corresponding Author: manish_singh17@rediffmail.com
}

\begin{abstract}
A simple, selective, rapid, precise and economical reverse phase high-pressure liquid chromatographic method has been developed as per ICH nomination for Development and Validation of Telmisartan in Tablet Dosage form By RP-HPLC Assay Method. The assay method was carried out by using a mobile phase consisting of Buffer Solution and Solution A ((Methanol and Acetonitrile (1:1)) in the gradient ratio. The detection was carried out by using HPLC Shimadzu LC with UV-Visible PDA at 298nm. The column was Hypersil BDS C-8 (12.5 cm X $4.0 \mathrm{~mm}, 5 \mu)$. The flow rate was selected as $1.2 \mathrm{ml} / \mathrm{min}$. The retention time of Telmisartan was found to be 8.3 min respectively. The developed method was validated in terms of specificity, accuracy, precision, linearity and system suitability. The optimized proposed method easy to handle and commercially used for the routine quality control checking of Telmisartan pharmaceutical combine tablets dosage form.
\end{abstract}

RASĀYAN J. Chem., Vol. 14, No.1, 2021

\section{INTRODUCTION}

Telmisartan is an ACE II receptor antagonist with actions similar to those of losartan. It is used in the management of hypertension ${ }^{1}$. The patients who have no ability of taking ACE inhibitors could be affected by this drug. It acts through interfering with the binding of angiotensin II to the angiotensin II AT1- receptor by binding reversibly and selectively to the receptors in vascular smooth muscle and the adrenal gland. Angiotensin II is the principle pressor agent of the rennin-angiotensin system, with effects that shows stimulation of synthesis, vasoconstriction and release of aldosterone, cardiac stimulation, and renal reabsorption of sodium. Micardis (Telmisartan) was approved for use by U.S. FDA in November 10, $1998^{2}$. It has the structural formula and given in Fig.-1.

The literature reveals that there are some of the methods have been reported for development and validation of Telmisartan by RP-HPLC. Most of the literatures are the development and validation of Telmisartan by UV spectrophotometry ${ }^{3-5}$, HPTLC and HPLC ${ }^{6,7}$ for Telmisartan development and validation of UV spectrophotometry ${ }^{8}$, HPTLC $^{9}$, and HPLC ${ }^{10}$ method for the development and validation of Telmisartan. An attempt was made to develop and report a simple, sensitive, validated and economic method for the development and validation determination of Telmisartan by RP- HPLC. ${ }^{11}$

\section{Materials}

\section{EXPERIMENTAL}

Telmisartan was obtained from Macleods Pharmaceuticals Ltd. in Baddi, India, as gift samples. Acetonitrile (HPLC Grade) and Methanol (HPLC Grade) were purchased from Central Drug House (P) Ltd., India. While Ammonium di hydrogen phosphate (AR Grade) from S.D. fine chemicals, India; Ortho-phosphoric acid (AR Grade) from Central 
Drug House (p) Ltd. The 0.45- $\mu \mathrm{m}$ nylon filters were purchased from Advanced Micro Devices Pvt. Ltd. Chandigarh, India. Mili-Q water was used throughout the experiment. The pharmaceutical formulation TELMED AH 40 (containing $40 \mathrm{mg}$ TEL, $12.5 \mathrm{mg} \mathrm{HCTZ}$ and $5 \mathrm{mg}$ Amlodipine) tablets were purchased from local pharmacy shops.

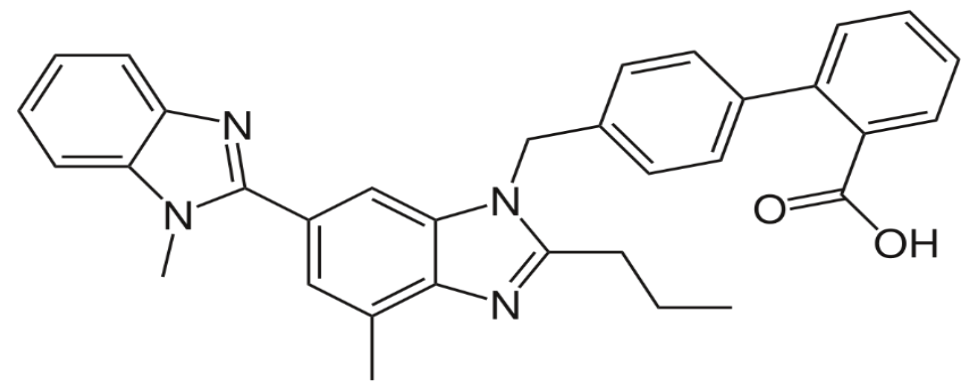

Fig.-1: Chemical Structure of Telmisartan

\section{Liquid Chromatographic Conditions}

Chromatographic condition were obtained using a stainless steel column (Hypersil BDS C-8 $12.5 \mathrm{~cm} \mathrm{X}$ $4.00 \mathrm{~mm}, 5 \mu$ ), which was maintained at $40^{\circ} \mathrm{C}$. The analytical wavelength was set at $298 \mathrm{~nm}$ and samples of $20 \mu \mathrm{l}$ were injected to HPLC system. The mobile phase was Ammonium Dihydrogen Phosphate (pH 3.0 adjust with Ortho phosphoric Acid) and Solution A ((Methanol and Acetonitrile (1:1)) in the gradient ratio at a flow rate of $1.2 \mathrm{ml} / \mathrm{min}$. The mobile phase was filtered through $0.45 \mu \mathrm{m}$ nylon filter and degassed for 10 min by sonication.

\section{Buffer Preparation}

Weigh accurately about 2 gm of Ammonium Dihydrogen Phosphate, transferred it in $1000 \mathrm{ml}$ of HPLC water. Then continuous string to dissolve it. After complete dissolved the buffer solution adjust the $\mathrm{pH}$ 3.0 with drop wise added Phosphoric Acid. Filter through $0.45 \mu$ nylon filter. Then sonicated it for 10 minutes to free from air bubbles.

\section{Preparation of 0.1N Sodium Hydroxide}

Weigh accurately about $4 \mathrm{gm}$ of Sodium Hydroxide, transferred it into a $1000 \mathrm{ml}$ volumetric flask, then Added $700 \mathrm{ml} \mathrm{HPLC}$ water and sonicated to dissolved properly. After that diluted to volume with water.

\section{Diluent Preparation}

Weigh accurately about $0.2 \mathrm{gm}$ of Sodium Hydroxide, transferred it into a $1000 \mathrm{ml}$ volumetric flask, then Added $700 \mathrm{ml}$ Methanol and dissolved properly. After that diluted to volume with methanol $(0.005 \mathrm{M}$ Methanolic solution).

Solution A: Methanol and Acetonitrile (1:1) ratio was prepared. It was mixed well and degas for 10 minutes to free from air bubbles.

Solution B: Buffer and Solution A (1:1) ratio was prepared. It was mixed well and degas for 10 minutes to free from air bubbles.

\section{Blank Solution}

Solution B was considered as blank solution. Buffer: Solution A (1:1) ratio was prepared. It was mixed well and degas for 10 minutes to free from air bubbles. The solution was loaded in HPLC and the chromatogram was recorded.

\section{Reference Stock Solution}

Weigh accurately about $40.0 \mathrm{mg}$ of Telmisartan Working Standard, transferred it in to $25 \mathrm{ml}$ volumetric flask, then Added $10 \mathrm{ml}$ diluent (0.005 M Methanolic solution) and Sonicate to dissolved and then diluted to volume with diluent (Conc.: $1600 \mathrm{ppm})$. 


\section{Reference Solution}

Take $2 \mathrm{ml}$ from reference stock solution to a $10 \mathrm{ml}$ volumetric flask. Then diluted to volume with Solution B (1:1 solution of Buffer and solution A), (Conc.: $320 \mathrm{ppm})$. The reference solution was loaded in HPLC and six injections ware taken from the same vial. The chromatogram was recorded, and the amount of the drug was calculated.

\section{Test Stock Solution}

Weigh accurately 20 tablets and calculated average weight. Then weigh and transferred 5 intact tablets into a $250 \mathrm{ml}$ of volumetric flask. Added $12.5 \mathrm{ml}$ of $0.1 \mathrm{~N}$ Sodium Hydroxide solution into the sample and shake until the tablets had completely disintegrated. Then added $140 \mathrm{ml}$ of methanol and sonicated for 10 min at $25^{\circ} \mathrm{C}$. Then the test solution was stir vigorously for $30 \mathrm{~min}$ at $300 \mathrm{rpm}$ by the mechanical shaker. After that it allowed to cool to room temperature. Then diluted to volume with methanol and mixed the solution properly. The test solution was centrifuge at $4000 \mathrm{rpm}$ for $10 \mathrm{~min}$. (Conc.: $800 \mathrm{ppm}$ ).

\section{Test Solution}

Take $4 \mathrm{ml}$ from test stock solution to a $10 \mathrm{ml}$ volumetric flask. Then diluted to volume with Solution B (1:1 solution of Buffer and solution A), (Conc.: $320 \mathrm{ppm})$. The test solution was loaded in HPLC and two injections ware taken from the same vial. The chromatogram was recorded, and the amount of the drug was calculated.

\section{Injection Procedure}

1. Gradient Blank for two times.

2. Blank Solution (Solution-B).

3. Reference Solution for six times.

4. Test Solution for two times.

5. Reference solution after every six injections of test solution and at the end of the sequence.

\section{Evaluation}

Integrate the Telmisartan peak.

Calculated the tailing factor of Telmisartan peak from reference solution.

Calculated \% RSD for the area of Telmisartan peak from the reference solution.

\section{System Suitability}

In the chromatograms obtained with reference solution ensure whether the following requirements are met:

1. The tailing factor for the Telmisartan peak should not be more than 2.0

2. The relative standard deviation of the areas from each peak of Telmisartan of first six injections must not be greater than $2.0 \%$.

3. The relative standard deviation of the areas from each peak of Telmisartan for all reference solution injections must not be greater than $2.0 \%$.

If the above conditions are not met, the HPLC system needs to be checked.

\section{Assay Method}

With the optimized chromatographic condition, a steady baseline was recorded, the reference solution was injected and the chromatogram was recorded. The retention time of Telmisartan was found to be 8.3 min. This procedure was repeated for the test solution obtained from the formulation.

\section{RESULTS AND DISCUSSION}

A chromatogram obtained from reference substances solution is presented in Fig.-2. The six Telmisartan reference substance areas are given below in Table-1. A chromatogram obtained from test substances solution is presented in Fig.-3. The two Telmisartan test substance areas are given below in Table 2. 


\section{Method Validation \\ Specificity}

The excipients in the tablets used in this study. The chromatograms obtained from the drug with the most commonly used interfering materials were compared with those obtained from the blank solution and placebo solution to determine the specificity of the method. The chromatogram observed in the study run time indicates the absence of interfering material peaks near the drug peak. This indicates the specificity of the proposed method. The interference result of this proposed method does not show any interference peak (Table-3) (Fig.-3).

Table-1: Areas of Telmisartan (Reference)

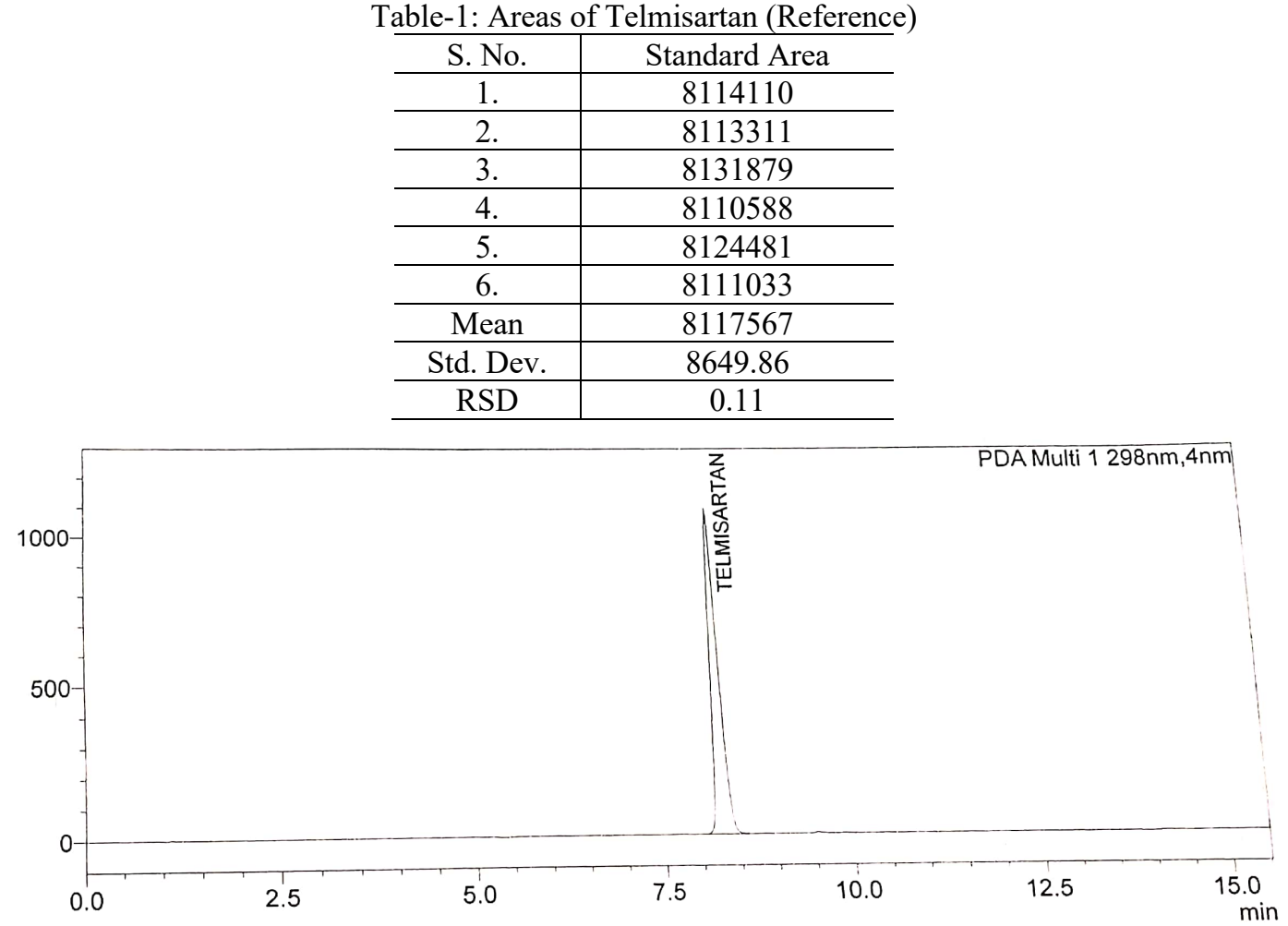

Fig.-2: Chromatogram of Telmisartan Reference Substance Solution



Fig.-3: Chromatogram of Telmisartan in Test Solution

Table-2: Areas of Telmisartan in Test Solution

\begin{tabular}{c|c|c|c}
\hline Area- 1 & Area- 2 & Mean Area & \% Assay of Telmisartan \\
\hline 8541308 & 8533220 & 8537264 & 105.8 \\
\hline
\end{tabular}


RASĀYAN J. Chem.

Vol. 14 | No. 1 |125-130| January - March | 2021

Table-3: Interference Details of Specificity Test

\begin{tabular}{c|c|c|c|c}
\hline Solution Name & $\begin{array}{c}\text { Retention Time of } \\
\text { The Peak(min.) }\end{array}$ & $\begin{array}{c}\text { Peak Observed Due } \\
\text { to Telmisartan }\end{array}$ & $\begin{array}{c}\text { Interference at } \\
\text { Telmisartan } \\
\text { RT(Yes/No) }\end{array}$ & $\begin{array}{c}\text { Purity Match } \\
\text { (NLT 990) }\end{array}$ \\
\hline Blank Solution & ND & ND & No & NA \\
\hline Placebo Solution & ND & ND & No & 1000 \\
\hline $\begin{array}{c}\text { Reference } \\
\text { Solution }\end{array}$ & 8.26 & $\begin{array}{c}\text { Peak Due to } \\
\text { Telmisartan }\end{array}$ & No & 1000 \\
\hline Test Solution & 8.28 & $\begin{array}{l}\text { Peak Due to } \\
\text { Telmisartan }\end{array}$ & No & 1000 \\
\hline
\end{tabular}

\section{Method Precision}

The intraday precision was performed at multiple samplings with proposed same conditions. And the intraday precision was no more difference. The result shows that the propose method are more reproducible. The precision results as represent as (Table-1 and 4). The percentage of relative standard deviation was calculated.

Table-4: Intraday method precision result of propose assay method (Telmisartan)

\begin{tabular}{c|c|c|c|c}
\hline S. No. & Telmisartan Area 1 & Telmisartan Area 2 & $\begin{array}{c}\text { Telmisartan Mean } \\
\text { Area }\end{array}$ & $\%$ Assay \\
\hline Method Precision 1 & 8487484 & 8491747 & 8489616 & 104.60 \\
\hline Method Precision 2 & 8497970 & 8480838 & 8489404 & 104.60 \\
\hline Method Precision 3 & 8507426 & 8519979 & 8513703 & 104.88 \\
\hline Method Precision 4 & 8561120 & 8551789 & 8556455 & 105.40 \\
\hline Method Precision 5 & 8488970 & 852027 & 8504623 & 104.76 \\
\hline Method Precision 6 & 8541007 & 8557554 & 8549281 & 105.31 \\
\hline & & & AVG. & 104.9 \\
\hline & & & STDEV & 0.3507 \\
\hline
\end{tabular}

\section{Accuracy}

According to the ICH guidelines ${ }^{12}$, the $\%$ recovery of drug was performed to the addition of known quantity of drug at proposed assay conditions. 50\%, 100\%, 150\% level was performed and every level has three determinations. The percentage recovery result represent as (Table- 5).

Table-5: Percentage Recovery Result of Telmisartan

\begin{tabular}{|c|c|c|c|c|c|}
\hline $\begin{array}{c}\% \text { w.r.t. Reference } \\
\text { Concentration }\end{array}$ & $\begin{array}{c}\text { API Added } \\
(\mathrm{mg})\end{array}$ & $\begin{array}{c}\% \text { Recovery of } \\
\text { Telmisartan }\end{array}$ & AVG. & $\%$ RSD & $\begin{array}{c}\text { Confidence } \\
\text { Interval } \\
\end{array}$ \\
\hline \multirow{3}{*}{$50 \%$} & 100.25 & 98.58 & \multirow{3}{*}{99} & \multirow{3}{*}{0.12} & \multirow{3}{*}{0.14} \\
\hline & 100.25 & 98.81 & & & \\
\hline & 100.32 & 98.76 & & & \\
\hline \multirow{3}{*}{$100 \%$} & 200.03 & 98.86 & \multirow{3}{*}{99} & \multirow{3}{*}{0.19} & \multirow{3}{*}{0.22} \\
\hline & 200.13 & 99.09 & & & \\
\hline & 200.07 & 99.23 & & & \\
\hline \multirow{6}{*}{$150 \%$} & 300.10 & 101.26 & \multirow{3}{*}{101} & \multirow{3}{*}{0.12} & \multirow{3}{*}{0.14} \\
\hline & 300.00 & 101.27 & & & \\
\hline & 300.07 & 101.05 & & & \\
\hline & Mean & 99.66 & & & \\
\hline & STD Dev & 1.1710 & & & \\
\hline & RSD & 1.17 & & & \\
\hline
\end{tabular}

\section{Linearity}

The concentration range of drug (Telmed-AH 40) was $5-15 \mu \mathrm{g} / \mathrm{ml}$. the linearity equation of Telmisartan was $y=26308.8085 x-377340.0683$. There value of the drug was 0.9989 of Telmisartan. The \%RSD value of the drug was less than $2 \%$. The HPLC of linearity of the drug show to (Fig.-4). The absorbance versus concentration plotted data of drug is given in Table- 6 . 
Table-6: Assay Study of Linearity Result of Telmisartan

\begin{tabular}{c|c|c|c}
\hline $\begin{array}{c}\text { \% w.r.t. Reference } \\
\text { Concentration }\end{array}$ & $\begin{array}{c}\text { Concentration in } \mu \mathrm{g} / \mathrm{ml} \\
\text { (Telmisartan) }\end{array}$ & Area & \%RSD \\
\hline 50 & 160.0000 & 3906154 & 0.13 \\
\hline 80 & 256.0000 & 6316059 & 0.20 \\
\hline 100 & 320.0000 & 7945331 & 0.00 \\
\hline 120 & 384.0000 & 9558770 & 0.09 \\
\hline 150 & 480.0000 & 12379256 & 0.13 \\
\hline
\end{tabular}

\section{CONCLUSION}

A simple, specific, precise and linear and accurate RP- HPLC method has been developed and validated for quantitative determination of Telmisartan in new tablet formulation. The method is very straightforward and all the parameters and results were found within the acceptance limit. And specific peak was well isolated from its others excipient peaks and which complete in total runtime of $15.5 \mathrm{~min}$, makes the developed its suitable for routine quality control analysis work.

\section{ACKNOWLEDGMENT}

We thank management of Maharishi Markandeshwar (Deemed to be University), Mullana- Ambala, India for providing necessary facilities. We are grateful for providing gift sample by Macleod's Pharmaceuticals Ltd., Baddi, India for providing standard.

\section{REFERENCES}

1. O.R. Rainier, Journal of the Medical Library Association, 100(1), 76(2012), DOI:10.3163/15365050.100.1.018.

2. C. Kumar, M. Kumar, V. Saini, S. Bhatt, A. Pandurangan, A. Malik, P. Pal and L. N. Shetty, Research Journal of Pharmacy and Technology, 12(6), 2747(2019), DOI:10.5958/0974360X.2019.00459.1

3. S.B. Wankhede, K.C. Raka, S.B. Wadkar and S.S. Chitlange, Indian Journal of Pharmaceutical Sciences, 72(1), 140(2010), DOI:10.4103/0250-474X.62239

4. M. K. Mishra. Rasayan Journal of Chemistry, 11(4), 1398(2018), DOI:10.31788/RJC.2018.1143056

5. Le Dinh Vu, Phan Tan Lap and Le Van Tan, Rasayan Journal of Chemistry, 11 (4), 1537(2018), DOI:10.31788/RJC.2018.1144061

6. Muni Krishnaiah A1, C. Rama Chandraiah, M. Srinivas and N. Devanna. Rasayan Journal of Chemistry, 13 (1), 24(2020), DOI:10.31788/RJC.2020.1315466

7. V. Sathiyanarayanan, H. Venkatasubramanian, and D. Easwaramoorthy, Rasayan Journal of Chemistry, 12(4), 2141(2019), DOI:10.31788/RJC.2019.1245419

8. S. D. Rathod, P.M. Patil, Santosh, S.A. Waghmare and P.D. Chaudhari. International Journal of Pharmaceutical Sciences and Research, 3(10), 3936(2012),DOI:10.13040/IJPSR.09758232.3(10).3936-39

9. S. B. Wankhede, M. R. Tajne, K. R. Gupta and S. G. Wadodkar, Indian Journal of Pharmaceutical Sciences., 69(2), 298(2007), DOI:10.4103/0250-474X.33164

10. M.S. Palled, M. Chatter, P.M. Rajesh and A.R. Bhat, Indian Journal of Pharmaceutical Sciences, 67, 108 (2005), DOI: 10.4103/0250-474X.54283

11. R.L.C. Ssidhar, S. Vidyadhara, B. Deepti and J. Suhasini, Oriental Journal of Chemistry, 30, 1815(2014), DOI:10.13005/ojc/320340

12. ICH Harmonized Tripartite Guideline, Stability Testing of New Drug Substances and Products, Q1A (R2), 1, 15(2003).

[RJC-6100/2020] 